\title{
Local History for Creative History Learning During the COVID-19 Pandemic
}

\author{
Nuhiyah ${ }^{1, *}$ Supriatna, Nana ${ }^{2}$ \\ ${ }^{1}$ Department of History Education, Graduate School, Universitas Pendidikan Indonesia, Jl. Setiabudi No. 229, \\ Bandung 40154 and Member of AGSI (Indonesian History Teacher Association) Banten \\ ${ }^{2}$ Department of History Education, Graduate School, Universitas Pendidikan Indonesia, Jl. Setiabudi No. 229, \\ Bandung 40154 \\ *Corresponding author. Email: nuhiyah@upi.edu
}

\begin{abstract}
This research in collaboration with AGSI Banten aims to explore History teachers' attitudes toward Local History for Creative History Learning during COVID-19 Pandemic. This research was conducted with applying a qualitative method to 106 participants of History teachers in Banten, Indonesia. Data collection techniques used were questionnaires, interviews, and observations. They were analyzed qualitatively based on the teachers' answers and quantitatively by using statistics descriptive. The results demonstrated that History teachers thought that Local History had a strategic role in Creative History Learning during the COVID-19 pandemic. Student's restricted learning spaces and saturation of online learning can be overcome by activity-based Local History Learning through exploring topics and historical resources coming from their surroundings, families and communities around them. The implementation of Creative Learning based on Local History depends on the locality of each region and the creativity of teachers in learning development. The local history material taught is the local history of Banten. The commonly used learning models are inquiry based learning and project based learning. Student products that have been produced are infographics, videos, short stories, articles, and autobiographies. The challenges experienced by History teachers in Local History Learning during the pandemic is about the difficulty of local history sources. History teachers considered the opportunity of learning local history as an approach in order to make students able to understand themselves and their environment through History Learning. These results encourage further research on local history learning resources and the development of local history learning media.
\end{abstract}

Keywords: COVID-19 Pandemic, Creative history learning, Local history.

\section{INTRODUCTION}

During this pandemic, new obstacles add to the long list of history learning challenges. Online History Learning is considered as a textual, boring and unattractive lesson for students [1]. Brown's research reveals that online learning impacts mental stress amongst students as a result of isolation [2]. Godsell's research reveals that online learning impacts the 'invisibilisation' of the marginalised and vulnerable students, who can and do easily disappear into the void of online learning [3].

Creative learning is one of the solutions to the challenges faced by history learning. In simple terms, creative learning can be distinguished by uncreative learning. This can be traced through two important subjects that cannot be separated in learning, namely teachers and students $[4,5]$. In contrast to uncreative learning that emphasizes learning by authority [5], In creative learning, teachers act as facilitators who use a variety of strategies, methods or approaches to create a happy learning and creative learners [6]. In the student's point of view, creative learning is a learning that allows students to develop their curiosity and desire to try and explore. Students have autonomy in doing positive activities, have the opportunity to socialize or cooperate with others in developing imagination and thinking in their own way $[5,7]$.

Due to the widespread spread of coronavirus, since March 2020 President of the Republic of Indonesia 
Joko Widodo asked the public to study, work, and worship from home. In response to these limitations, creative history learning facilitates learning that connects the materials learning to students' life. Namely 'making connections', an aspect of creative history learning initiated by Bruner [8] and Cooper [9] that emphasizes students to make connections between places, historical events and timescales through learning materials in the national curriculum for History. Creative history learning is learning that brings students closer to historical events around students, including local history [6].

Local history is a study of past events, or people or groups, in specific geographic areas. The focus of local history can be the place itself, the people who live there or events that occur in a specific location. Local history learning can re-attract interest to students and realize their position in a larger network of history and context. $(10,11]$. Teachers should provide students with the best learning experience through online learning without any warning or preparation time [12, 13]. Teachers need to design learning activities that allow students to use historical resources to create local history learnings, especially by connecting students with their community history [14].

Local history has an important role in creative history learning during the pandemic. Local history presented by teachers through creative learning can be a contextual and fun learning for students [6].Therefore, the purpose of this study was to investigate how History teachers' attitudes toward Local History for Creative History Learning during COVID-19 Pandemic. This study is expected to provide an overview of the teachers' attitudes on Local History teaching opportunities in high schools. In addition, the results of this study are also expected to be a reference for teaching improvement for the history teacher.

\section{METHOD}

This research was conducted by applying a qualitative method to 106 participants of History teachers in Banten, Indonesia. This research in collaboration with AGSI (Indonesian History Teachers Association) Banten is as a follow-up to the Local History Online Learning Workshop conducted by AGSI Banten and followed by history teachers in order to increase the creativity of teachers in building creative history learning based on local history during the pandemic. Respondent demographics can be seen in table 1 .
Table 1. Respondent demographics

\begin{tabular}{|l|l|l|}
\hline Demographic Variables & N & $\%$ \\
\hline Gender & 46 & 42,9 \\
\hline Male & 60 & 57,1 \\
\hline Female & 55 & 51,9 \\
\hline Education & 4 & 3,8 \\
\hline Bachelor of History Education & \multicolumn{2}{|l|}{} \\
\hline $\begin{array}{l}\text { Bachelor of History } \\
\text { /History Of Islamic Civility }\end{array}$ & 10 & 9,4 \\
\hline Bachelor of Science (not history) & 11 & 10,4 \\
\hline Master of History Education & 26 & 24,5 \\
\hline Master of Science (not history) & 0 & 0 \\
\hline Teacher Professional Education & & \\
\hline Teaching Experience & 11 & 10,4 \\
\hline$<5$ years & 19 & 17,9 \\
\hline 5 - 10 years & 42 & 39,6 \\
\hline 10 - 15 years & 15 & 14,2 \\
\hline 15 - 20 years & 17,9 \\
\hline$>20$ years & \multicolumn{2}{|l|}{} \\
\hline
\end{tabular}

Table 2. Respondent's School Demographics

\begin{tabular}{|l|c|c|}
\hline Demographic Variables & N & $\%$ \\
\hline School Level & 85 & 80,2 \\
\hline Senior High School & 13 & 12,3 \\
\hline Vocational Schools & 8 & 7,5 \\
\hline Islamic School & \multicolumn{2}{|l|}{} \\
\hline School Type & 94 & 88,7 \\
\hline Public & 12 & 11,3 \\
\hline Private & 11 & 10,4 \\
\hline City of School & 30 & 28,3 \\
\hline Serang City & 14 & 13,2 \\
\hline Serang regency & 15 & 14,2 \\
\hline Pandeglang regency & & \\
\hline Lebak regency & & \\
\hline
\end{tabular}




\begin{tabular}{|l|c|c|}
\hline Cilegon City & 10 & 9,4 \\
\hline Tangerang City & 10 & 9,4 \\
\hline South Tangerang City & 11 & 10,4 \\
\hline Tangerang regency & 5 & 4,7 \\
\hline
\end{tabular}

Data collection techniques used were questionnaires, interviews, and observations. Research instruments include questionnaires, interview guidelines and observation guidelines created based on creative learning indicators. There are 20 statements in the questionnaire with 5 answer options ranging from the "Always, Often, Sometimes, Rarely, Never" scales that are organized based on creative learning indicators. There are 15 open-ended questions about local history learning during the pandemic that are used to explore the learning of local history during the pandemic that has been done by history teachers.

They were analyzed qualitatively based on the teachers' answers and quantitatively by using statistics descriptive. The qualitative data obtained was analysed using three continuous flows of activities, namely: data reduction including data triangulation, data presentation, and conclusion drawing. Data reduction is used for selecting, centralizing or simplifying rough data that arises from each data collection technique. Data triangulation is used to check the validity of the data. This validity is obtained by comparing the results of interviews and questionnaires that have been conducted.

\section{RESULT AND DISCUSSION}

\subsection{Creative History Learning during the Pandemic}

Aspects explored in this study include three aspects of creative learning, namely learning planning, learning implementation and learning evaluation. As stated by Dezuani and Jetnioff [15] and Supriatna [6] that creative learning is planning, organizing activities and teaching and learning processes that are imaginative and innovative with a curriculum with learning strategies for the purpose of developing students' creativity.

In the definition, there are several elements related to creative learning including learning planning and implementation of learning. In addition, the aspect of creative learning is also inseparable from learning evaluation. It has a special characteristic that is to produce students who are not only able to work on various training questions but can also interpret learning materials and connect them with daily life $[6,16]$.

The results of the data collection that has been done both questionnaire results, interviews and observations to respondents can describe how history teachers have implemented creative learning in history lessons during the pandemic. Figure 1 contains questionnaire data on history teachers' experience in

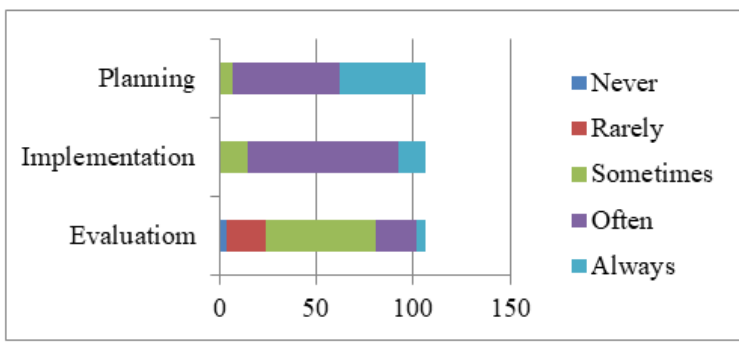

creative history learning during the pandemic.

Figure 1. Teachers' experience in creative history learning during pandemic

Based on figure 1, the planning and implementation aspects of creative learning show a positive response (Sometimes - Always). This indicates that history teachers have mastered the planning and implementation of creative learning during the pandemic because most history teachers have had more than 10 years of learning experience in teaching history and many of them improve their quality in learning by continuing master's education in both the field of history education and other fields of science.

History teachers have conducted creative learning both in learning planning by trying to plan a meaningful learning ranging from planning strategies, models and learning methods, reflecting from previous learning experiences to drawing up lesson plans [6]. History teachers have also carried out creative learning by developing various learning plans through their understanding and their own way or style by making students the main subject of learning (student-centered learning) [16] [17].

Another known fact from figure 1 is that the history teacher's response to the learning evaluation still shows a negative response (Never - Always). History Teachers still make objective tests as the main evaluation. Therefore, students are required to memorize and remember learning materials. History teachers also still consider that students' ability to 
answer questions is much more important than the ability of students in interpreting learning materials and connecting them with daily life [18].

\subsection{Local History For Creative History Learning during the Pandemic}

\subsubsection{The Urgency of Local History Learning During The Pandemic}

Regarding the urgency of local history learning during the pandemic, the results show that history teachers see that local history has a strategic role in creative history learning during the pandemic. Brown's and Godsell's research reveals that online learning impacts mental stress amongst students as a result of isolation [7, 8]. Student's restricted learning spaces and saturation of online learning can be overcome by activity-based learning. Local History Learning through exploring topics and historical resources coming from their surroundings, families and communities around them $[6,19,20]$. In addition, local history learning makes students do learning activities without breaking the rules of physical distancing as an effort to prevent the COVID-19 virus because learning is done through the nearest environment of students, one of whom is their family.

\subsubsection{How to Connect Local History Topic to The History National Curriculum}

In The Syllabus of History subjects, local history topics have little discussion. Therefore, planning local history learning requires the ability of teachers in associating local History to the historical materials in the curriculum [21]. To connect local history content to the history curriculum, the first step is to analyze the basic competencies contained in the syllabus. The next stage is to develop a lesson plan. Lesson plan is prepared to determine what kind of models, methods, media and evaluations will be conducted to make learning more conducive $[22,6]$. In the lesson plan, basic competencies are analyzed to determine indicators of competency achievement that will determine what local historical materials can be connected in the learning.

\subsubsection{Local History Topic}

History teachers gave varied answers on local history topics taught during this pandemic. The author concluded that the topic of local history varies according to the local history of each region, but generally in the form of the history of figures, cultural history, place, cultural heritage buildings, education, the
History of the Sultanate of Banten and the History of Banten Province, and the history of events. Teachers try to encourage students to research about the local history of their immediate surroundings, such as their family [6]. If it is not available then they directed to the neighborhood where they live, up to the district / city and Banten Province.

In detail, the following are some of the local history topics taught by history teachers, 1) History of figures such as The Islamic scholars around the area where students live who have a role to play in their respective regions. One of the heroes from Banten who is most often taught in many districts / cities is Brigjend. KH. Syam'un. 2) History of cultures such as Hindu-Buddhist/Islamic Heritage in the area where students live. 3) History of places such as The origin of the name of the village / the area where students live. 4) The History of historical buildings or cultural heritage sites in the area where students live. 5) History of the Sultanate of Banten and the History of Banten Province such as Sultan Ageng Tirtayasa, Debus Banten, Relics of the Sultanate of Banten, Inscriptions or archaeological sites in Banten, Banten in the Preliteracy Period, Hindu-Buddhism, and Islam and the Colonial and Independence Period, Cultural Acculturation in Banten, the founding figures of banten province during the reformation, History of the formation of Banten Province. 6) History of Education is still related to the History of Banten, such as Mathlaul Anwar Education Foundation in Pandeglang and AlKhairiyah Education Foundation in Cilegon and 7) History of events is still Related to the History of Banten, such as Geger Cilegon.

\subsubsection{Local History Learning Resources}

Learning resources or teaching materials used by history teachers in the study of local history during the pandemic is quite limited but varied namely the internet, newspapers, local history books written by various institutions, national and international historians. Some organizations also make some local history teaching materials for students such as "Banten Local History" a book written by History Teacher Deliberations (MGMP Sejarah) Banten and Tangerang Local History Module. In addition, history teachers also created individual local history learning modules.

During this pandemic, teachers guide students to learn through primary historical sources such as interviews with families, community leaders and local residents. Everyone can be a historical figure in his day. Parents of rural students who are engaged in agriculture 
can be a resourceful person to tell about the joys and sorrows of being a farmer. Their story could be linked to larger historical events such as the glory of the era of trade and shipping in Indonesia [6]. It is part of the first person historical presentation method initiated by Morris, namely by presenting historical actors in learning [23]

\subsubsection{Applications/platforms used by history teachers}

Online learning is closely related to the use of digital technology. Various learning applications or platforms are used to support online learning. Teachers who mastering information and communication technology will provide added value in the learning process and will automatically facilitate the activities of the teacher theirself [24]. During this pandemic, teachers are required to be more creative, innovative and utilize online learning media in preparing the learning process for students [24]. The learning applications/platforms used by history teachers in local history learning can be seen in Figure 2.

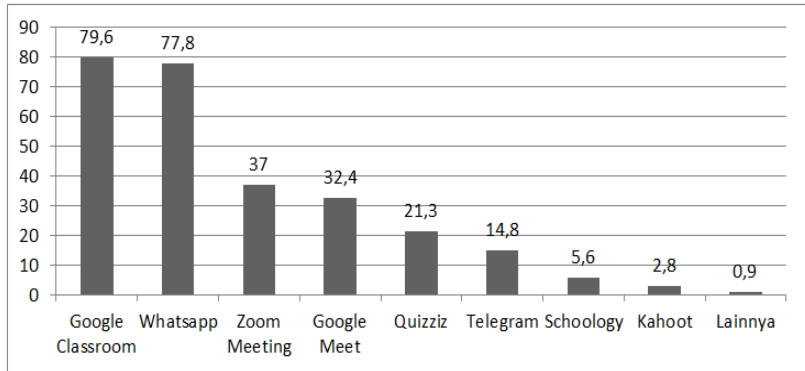

Figure 2. The learning applications/platforms used by history teachers

Based on figure 2, it is known that the most widely used learning applications/platforms in local history learning during the pandemic are google classroom and whatsapp. It is considered easy to operate by history teachers, easily accessible to students and does not cost a lot and can accommodate many students. History teachers carry out learning activities by sharing materials with students through the platform.

Google Classroom is a web-based classroom management platform [25, 26]. Google classroom becomes a communication tool between teachers and students. Teachers can distribute materials, send announcements, create assignments, and hold class discussions. Students can also share resources and interact with each other [26].

Video conference applications become the third and fourth most used namely zoom meeting and google meet. The zoom app has a video conferencing feature that allows online face-to-face interaction. It can be downloaded for free. [27]. Video conference applications were only used by history teachers at the first meeting at the beginning of the semester to discuss learning contracts and once for a single basic competency to provide reinforcement to students about learning materials. Video conference applications are rarely used by history teachers due to quota, signal and device limitations experienced by both students and history teachers.

\subsubsection{Learning methods and Models Used by History Teachers}

Learning models and methods are two important components of learning. Choosing the right learning models and methods will increase the effectiveness of learning [28]. In the implementation of local history learning during the pandemic, history teachers used a variety of learning models and methods to avoid saturation of students. In addition, the selection of learning models and methods are chosen based on the needs of learning materials and relies heavily on the teachers' creativity. Some models and methods of local history learning implemented by history teachers during

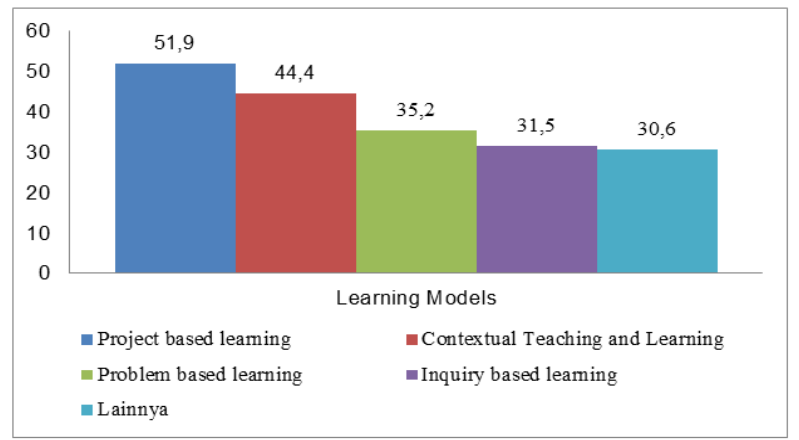

the pandemic can be seen in figure 3 .

Figure 3. The learning applications/platforms used by history teachers

Based on figure 3, the most widely used learning models are project based learning, contextual-teaching learning, problem-based learning and inquiry-based learning. The four learning models stimulate students to conduct activity-based learning. Problem-based learning models stimulate students to be more aware of the historical problems present in their surroundings [28]. Inquiry-based learning stimulates students to search for information both from the internet and from nearby environments such as families related to historical material studied. The importance of inquiry-based learning (IBL) activities, which require students to form their own conclusions about the past, based on an 
analysis of sources [29]. These resources were processed into a project-based work that is realized in project-based learning. Peterson \& Miller [30] describe Project Based Learning (PBL) as carefully designed and monitored cooperative learning tasks that help students achieve future goals and can help students engage more actively in their learning experiences. Teachers guide various activities of students ranging from product planning, information search process to product creation.

In detail, the following are some examples of the implementation of local history learning models during the pandemic: a) For Grade 10, in learning materials about Islamic Kingdoms in Indonesia, teachers used Contextual-Teaching Learning and Inquiry-based Learning. Students seek information about examples of evidence of Islamic heritage or culture that is still applicable to the lives of Indonesians the environment around the students. Through project-based learning, students create a work on examples of evidence of Islamic heritage or culture that still applies to the lives of Indonesian people today in the environment around students. b) For Grade 6, In learning materials about the role of national and regional figures in the fight for Indonesia's independence teachers used ContextualTeaching Learning and Inquiry-based Learning. Students were looking for information about regional leaders who fight for Indonesia's independence in the environment around students. Through project-based learning, students created a work about theirself and regional figures who fight for Indonesia's independence in the environment around students in the form of writing, oral and / or other media. c) For Grade 12, in learning material about political life and economy of the Indonesian nation in the early days reform teachers used Contextual-Teaching Learning and Inquiry-based Learning. Students interviewing their families living during the Reformation on the policies of the Reformed government. Through project-based learning, students created an autobiography about them, their family and various reformed government policies in the form of writing, oral and/or other media.

\subsubsection{Learning methods and Models Used by History Teachers}

Related to the project based learning model that is widely used by history teachers in history learning, it produced many products from the work of students. The resulting products vary from infographics, videos, short stories, articles, and autobiographies. Some of these products are uploaded to social media or to google classroom and will be rated by teachers.
Assessment techniques conducted in local history learning during the pandemic generally use qualitative approach based on process. Assessments are conducted from planning to the resulting product [6]. Assessment can be in the form of written comments submitted by the teacher to students personally. This comment also contains feedback and suggestions on the performance of students for future improvements.

\subsection{Opportunities and Obstacles Experienced by History Teachers}

The opportunity to learn local history for history teachers is considered as one of the approaches for students to understand themselves, their families and their environment through history learning. It is expected that students will be formed who appreciate local history, local wisdom and pride in their locality without losing their nationalism as an Indonesian nation $[19,20]$.

The obstacles felt by history teachers in the study of local history during the pandemic is about the difficulty of local historical sources. Therefore, history teachers hope that the government can encourage local history writing and make local history as one of the local content in schools.

\section{CONCLUSION}

Based on the result of this study, History teachers have conducted creative learning during the COVID-19 Pandemic. History Teachers see that Creative history learning through local history during the pandemic has a strategic role to provide an effective and efficient learning experience and in accordance with the current emergency. By studying the local history, students can explore the sources of history in the surrounding environment ranging from the family environment to the community where they live. Referring to the importance of studying local history, history teachers hope the government can encourage local historical Literacy and make local history as one of the local contents in schools. These results encourage further research on local history learning resources and the development of local history learning media.

\section{ACKNOWLEDGMENTS}

The authors wish to thank Indonesian History Teacher Association (AGSI) Banten for this collaboration research. Special gratitude is also addressed to the Lembaga Pengelola Dana Pendidikan (LPDP) which has supported my master program. 


\section{REFERENCES}

[1] Brigida Intan Printina, Theresia Sumini, History Lessons During the Covid-19 Pandemic in DIY (Case Study Based on Desca Approach with the Principle of Independent Learning), Social, Humanities, and Education Studies (SHEs): Conference Series 3 (2) (2020) 267- 278. https://jurnal.uns.ac.id/shes .

[2] Marjorie Ann Brown ,Teaching and learning History in the time of the COVID-19 pandemic: reflections of a senior school history teacher, Y\&T n.24 Vanderbijlpark Dec. 2020, http://www.scielo.org.za/scielo.php?script=sci_artt ext\&pid=S2223-03862020000200015..

[3] Sarah Godsell, Teaching History teachers during COVID-19: Charting poems, pathways and agency, Y\&T n.24 Vanderbijlpark Dec. 2020. DOI :http://dx.doi.org/10.17159/22230386/2020/n24a3.

[4] NACCCE. NACCCE Report: All Our Futures: Creativity, Culture and Education. NACCCE, 1999.

[5] Yu-Sien Lin, Fostering Creativity through Education-A Conceptual Framework of Creative Pedagogy, Creative Education 2011. Vol.2, No.3, 149-155.

DOI:https://doi.org/10.4236/ce.2011.23021.

[6] Nana Supriatna, Nana Maulidah, Creative Pedagogy: Fostering Creativity in History And Social Studies Learning. Bandung: Rosda, 2020.

[7] Mark Selkrig \& (Ron) Kim Keamy, Creative pedagogy: a case for teachers' creative learning being at the centre, Teaching Education, DOI: http://dx.doi.org/10.1080/10476210.2017.1296829.

[8] J. S. Bruner, The Process of Education. Cambridge, MA: Harvard University Press, 1963.

[9] Hilary Cooper, What is creativity in history?, International Journal of Primary, Elementary and Early Years Education, Education 3-13, 46:6, 636647.DOI:https://doi.org/10.1080/03004279.2018.1 483799.

[10] R Gunawan, H Rachmah, Local history online learning strategies: teacher's perception. 3rd International Conference on Environmental Geography and Geography Education. IOP Conf. Series: Earth and Environmental Science 747 (2021) 012010. IOP Publishing. DOI: https://doi.org/10.1088/1755-1315/747/1/012010
[11] Carol Kammen. Cornell: Glorious to View. Ithaca: Cornell University Press, 2003.

[12] GeorgeOrlov, Douglas McKee, JamesBerry, Austin Boyle,Thomas DiCiccio, Tyler Ransom, Alex Rees-Jones, JörgStoye, Learning during the COVID-19 pandemic: It is not who you teach, but how you teach, Economics Letters, Volume 202, May 2021, 109812, DOI :https://doi.org/10.1016/j.econlet.2021.109812.

[13] Matthew A. Kraft, Nicole S. Simon, Melissa Arnold Lyon, Sustaining a Sense of Success: The Importance of Teacher Working Conditions During the COVID-19 Pandemic . (EdWorkingPaper 2020: 20-279). Retrieved from Annenberg Institute at Brown University: DOI : https://doi.org/10.26300/35nj-v890

[14] Clarke, W.G. \& Lee, J.K. The promise of digital history in the teaching of local history. The Clearing House: A Journal of Educational Strategies, Issues, and Ideas, 2004, 78 (2), 84-87.

[15] M. Dezuani, Jetnioff, A, Creative Pedagogies and Contemporary School Classroom. Journal of Creative Learning. New York : Routledge (Taylor \& Francis Group).

[16] Leon R. de Bruin, Anne Harris, Fostering Creative Pedagogies in Australian Schools, Australian Journal of Teacher Education, Vol 12. Issue 9. DOI :http://dx.doi.org/10.1080/10476210.2017.129682.

[17] Mark A. Runco, Garrett J. Jaeger, The Standard Definition of Creativity, Creativity Research Journal, 24:1, 92-96, DOI: https://doi.org/10.1080/10400419.2012.650092

[18] Said Hamid Hasan, Indonesian History Education : Issues in Ideas and Learning, Bandung : Rizki Press, 2012

[19] James T. Webb, Elizabeth A. Meckstroth, Stephanie S. Tolan, Guiding the Gifted Child, Great Potential Pr Inc, 1994.

[20] J.A. Brewer, P.H. Miller, Introduction to Early Childhood Education. Boston:Allyn and Bacon, 2007.

[21] Iin Purnamasari dan Wasino, Development of Historical Learning Model Based on Local History Site In Temanggung District High School, Paramita Vol. 21 No. 2 - Juli 2011 [ISSN: 08540039], pp. 202-212. 
[22] William G. Bowen and Michael S. McPherson, Lesson Plan, Princeton University Press , 2018. DOI : https://doi.org/ 10.1515/9781400881369

[23] R.V. Morris, Bringing History to life : First Person Historical Presentation in Elementary and Middle Classrooms. New York: Rowman and Littlefield Education, 2009.

[24] Fajriana, F., \& Safriana, S. Analysis of Teacher Readiness in Online Learning. Indonesian Journal of Science Education, 9(2), 293-304, 2021

[25]P. Jakkaew, and S. Hemrungrote, Deployment of Google Classroom to Enhance SDL Cognitive Skills: A Case Study of Introduction to Information Technology Course. International Conference on Digital Arts, Media and Technology (ICDAMT), 2017.

[26] D A Fitriningtiyas, N Umamah , and Sumardi, Google classroom: as a media of learning history, IOP Conf. Series: Earth and Environmental Science 243 (2019) 012156. IOP Publishing. doi: https://doi.org/10.1088/1755-1315/243/1/012156

[27] Andrew T. Ching, Tülin Erdem, Michael P. Keane Learning Models: An Assessment of Progress, Challenges, and New Developments, marketing sciences, Vol. 32, No. 6, November-December 2013, pp. 913-938.

[28] Wieseman, Katherine C.; Cadwell, Doni, Local History and Problem-Based Learning, Social Studies and the Young Learner, v18 n1 p11-14 Sep-Oct 2005.

[29] Michiel Voet, Bram De Wever, History teachers' conceptions of inquiry-based learning, beliefs about the nature of history, and their relation to the classroom context. Teaching and Teacher Education, Volume 55, April 2016, Pages 57-67, DOI: https://doi.org/10.1016/j.tate.2015.12.008.

[30] Wieseman, Katherine C.; Cadwell, Doni, Local History and Problem-Based Learning, Social Studies and the Young Learner, v18 n1 p11-14 Sep-Oct 2005. 